\title{
Impact of Faculty and Student Readiness on Virtual Learning Adoption amid Covid-19
}

\author{
Impacto de la Preparación de Profesores y Estudiantes en la \\ Adopción del Aprendizaje Virtual en Medio de Covid-19
}

\author{
Mohammad Rokibul Kabir* \\ East Delta University, Bangladesh \\ University Malaysia Perlis, Malaysia
}

\begin{abstract}
The deadly effect of Covid-19 has changed the world dramatically. The education sector is one of the worst sufferers due to the official closures of educational institutions worldwide. The government of Bangladesh has declared all the oncampus activities shut in March 2020. This paper explains the effect of faculty and student readiness in adopting virtual classes considering the mediating effect of technology adoption intention. Teachers and students from private and public universities in Bangladesh are surveyed for this research. The findings revealed that the private universities are well ahead of providing online education as their faculty and students are ready with logistics and mindset to adopt technology-based virtual learning while the public university stakeholders are yet to initiate it. It is concluded that the lack of readiness of public universities will create a massive gap between public and private university education and rural and urban students as well. The proposed model of this research can help the policymakers and the government in formulating policy guidelines for bringing all the students and teachers on virtual education platforms irrespective of their university affiliations.
\end{abstract}

Keywords: Covid-19; Higher education; Social imbalance; Technology adoption; Virtual learning.

El efecto letal de Covid-19 ha cambiado el mundo de forma espectacular. El sector de la educación es uno de los más afectados por el cierre oficial de las instituciones educativas en todo el mundo. El gobierno de Bangladesh declaró cerradas todas las actividades en el campus en marzo de 2020. Este artículo explica el efecto de la preparación de profesores y estudiantes en la adopción de clases virtuales considerando el efecto mediador de la tecnología. Para esta investigación se lleva a cabo una encuesta a profesores y estudiantes de universidades públicas y privadas de Bangladesh. Los hallazgos revelaron que las universidades privadas están muy por delante de brindar educación en línea, ya que sus profesores y estudiantes cuentan con la logística y la mentalidad para adoptar el aprendizaje virtual, mientras que las universidades públicas aún no lo han iniciado. Se concluye que la falta de preparación de las universidades públicas creará una brecha masiva entre la educación universitaria pública y privada y los estudiantes rurales y urbanos. El modelo propuesto de esta investigación puede ayudar a los formuladores de políticas y al gobierno en la formulación de pautas de políticas para atraer a todos los estudiantes y profesores a las plataformas de educación virtual, independientemente de su afiliación universitaria.

Descriptores: Covid-19; Educación superior; Desequilibrio social; Adopción de la tecnología; Aprendizaje virtual.

*Contacto: rokibul.k@eastdelta.edu.bd

ISSN: 2254-3139

www.rinace.net/riejs/

revistas.uam.es/riejs
Recibido: 1 de septiembre 2020

$1^{\text {a }}$ Evaluación: 13 de octubre 2020

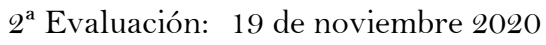

Aceptado: 16 de diciembre 2020 


\section{Introduction}

The world has become an abnormal and strange place to live in due to the effect of Covid19. Many countries have already implemented travel restrictions (both within and outside) to protect the citizens from the pandemic and to avoid the spread of the disease. Several steps are being taken including physical distancing, self-isolation, or quarantine; and urging residents to live at home (Bedford et al., 2020). Most importantly, the conventional education system is shut down due to Covid-19 outbreak (McIntyre, 2020).

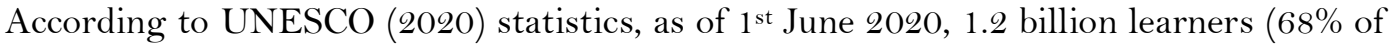
the world's total enrolled learners) were affected globally due to the closure of the educational institutions. Bangladesh is not an exception as all educational institutes in the country have been kept closed since $17^{\text {th }}$ March 2020. Hence, embracing technology for education is no more an option but a reality. However, the concern is to identify whether the faculty members and students in the higher education system of Bangladesh are ready to embrace technology-based online education system. Though many of the institutions have started taking online classes, the infrastructure is not developed enough with the necessary tools for the faculty members and the students. The faculties are not appropriately trained as well to conduct courses in this system (Askari, 2020). It is argued that student and faculty readiness is strongly associated with the available logistic supports like electronic devices and internet connectivity. Thus, the option of online education is not fruitful for Bangladesh yet when the internet access is insufficient along with unavailability of gadgets like smartphone, laptop, computer etc. to the mass level students and in some cases to the faculty members (Uddin, 2020). Likewise, internet speed is going down gradually because of unexpected increase in demand (Islam, 2020), which is causing a significant disruption in online education (Askari, 2020). Moreover, some individuals feel shy about coming to the video or expressing an opinion on the online platform. So, they are lagging behind as one-directional learning is not feasible enough to ensure quality education (UNESCO, 2020). Thus, all these difficulties are affecting higher education in Bangladesh.

The earlier studies on virtual learning mainly discussed various programs, challenges and suggestions for implementing online learning in Bangladesh to ensure successful and high-quality teaching and learning. Nonetheless, most of these studies are concentrated on small sample size and scope. Some models were also used that adhered to different techniques and methods to define and evaluate the ground realities of online learning (Khan et al., 2012). However, the Covid-19 scenario forced to rethink about virtual learning and initiate research considering faculty and student readiness amid the pandemic. In fact, the transition to virtual distance teaching has now reached the stage that faculty may not only opt-out of it, but preferably online learning is also an unavoidable reality (Cutri \& Mena, 2020). Similarly, students must get prepared to welcome them. Thus, it is essential to assess faculty and students' readiness to adopt the new trend of education, with particular regard to Covid-19 scenario.

Faculty readiness for virtual learning means psychological and physical (technological) preparedness of the faculty members to establish and incorporate online instructions and assessments (Adnan, 2018; Hashim \& Tasir, 2014). Earlier studies have shown that teaching virtually over the internet often require a great deal of time, most commonly taken from the devoted time for research and studies (Bussmann et al., 2017; Raffo, Fisher, $\&$ Raffo, 2015). As a consequence, senior professors are found to consider the virtual 
classes less important than junior lecturers do (Martin et al., 2019). Hence, faculty readiness to readjust the time and efforts may play a crucial role in the success of online teaching and assessment.

Khalifeh and others (2020) claimed students' readiness (SR) as the prerequisite for successful technology-aided learning. They identified three forms of SR called students' psychological readiness (SPR), students' skills for collaborative learning (SSCL) and students' technology readiness (STR). SPR reflects on the mindset of a student as it influences the output of a learning experience based on technology (Coopasami, Knight, \& Pete, 2017). SSCL indicates a student's interpersonal and intrapersonal qualities (Noroozi \& Hatami, 2019; Slof, Nijdam, \& Janssen, 2016). To resolve the interpersonal dispute and to establish a healthy relation among the peers of a group, interpersonal skillsets are essential (Notari, Baumgartner, \& Herzog, 2014; Phielix, Prins, \& Kirschner, 2010). For students to navigate their educational experiences via the notions of individuality and self-directedness in studying, intrapersonal skillsets are vital factors (Smith, 2005). Finally, STR leads to a student's willingness to incorporate emerging technology in the context of education to reach goals (Parasuraman \& Colby, 2007). STR is a blend of favourable and unfavourable views linked to technology that is believed to differ from each other (Godoe \& Johansen, 2012).

Considering the mediating effect of intention to adopt technology is a new dimension of this research and to the distance learning literature as well. A few studies have assessed the mediating impact of other factors like techno-stress on the adoption of technology for education (Joo, Lim, \& Kim, 2016). However, this research is unique in the higher education research of Bangladesh and other similar developing countries because it explained the mediating effect of intention to adopt technology for higher education. Thus, this study is an attempt to assess the degree to which student readiness (SR) and faculty readiness (FR) influence the adoption of virtual classes (AVC), considering the mediating effect of intention to adopt technology for virtual learning (IATV). The findings of this study will be beneficial for the stakeholders of the education sector in Bangladesh including universities, educators, learners, parents, policymakers and the government in dealing with this pandemic in terms of the higher education. It will also help other developing countries who are struggling with their education management during the epidemic and afterwards.

\section{Review of the literature}

In university education, online classes are prominent though this trend has been intensified due to the Covid-19 pandemic (Allen \& Seaman, 2016; Garrison, 2011). The outbreak of the coronavirus contagion has impacted many aspects of society and education, in particular, is the worst sufferer (Flores \& Gago, 2020). Online distance learning has been introduced as an immediate response to reduce the burden of the pandemic on learning worldwide (Bozkurt \& Sharma 2020). In a way, Covid-19 has created new possibilities for the world, especially for the countries which are yet to adopt technology-based education, to change the way of providing education and to turn its focus to new technology. On this background, universities must use the opportunity to improve their fact-based policies (Toquero, 2020), which requires the faculties and students to be committed and prepared both psychologically and technologically. 
The success of online learning in higher education system relies on the commitment of the faculty to ensure quality learning and instructions (Tabata \& Johnsrud, 2008). Since a significant portion of the success of education depends on mindset, the instructors must change their perception towards online classroom and adoption to technology for the sake of students' betterment. In this crisis moment, technology has created a revolution in the education system, which is embraced by all more or less (Shenoy, Mahendra \& Vijay, 2020). König, Jäger-Biela and Glutsch (2020) argued that technology-based resources, especially digital teaching skills and teachers' training facilities to gain technologyenabled capabilities and abilities, are crucial in adjusting to virtual education during educational disruptions due to Covid-19. However, the mere existence of technical hardware does not inherently contribute to the advancements in distance learning ( $\mathrm{Li} \&$ Ma 2010). Though the incorporation of technology in the educational environment requires technological and infrastructural development, faculty and learners must both be trained and assisted through the use of modern technologies. The progress in online education would remain inadequate if the deficient ones are not well prepared to use technology-oriented resources. Hence, the success of online education will require the teachers and students to be well trained in using technology-based tools.

In successful virtual learning, there should be several methods for exploring and sharing information, including asynchronous and synchronous learning activities (Liu et al., 2010; Osman, 2005), video lectures, compressed videos, website viewing, and various methods of communication like chat rooms, email, and webcam conversation (Balkin et al., 2005). Along with the active interaction and involvement, students can understand the materials and can apply it better when real-world issues and situation occurs (Eble, 1994). Among different aspects of online education, assessment of students has become a big challenge. The traditional campus-based examinations have now been discontinued by universities internationally. The shift from conventional on-campus instruction to virtual teaching has a detrimental effect on the assessment of students, and that necessitates continuous assessments to become an integral part of online learning (Sahu, 2020).

While faculty and students are now in the process of switching to virtual learning environments, the epidemic of Covid-19 has a catastrophic effect on students and university staff's mental health (Sahu, 2020). It induced the education community, including students, a considerable amount of tension. This distress might lead to detrimental impacts on students' academic and psychological wellbeing (Al-Rabiaah et al., 2020; Kafka, 2020). If proper care is not taken to ensure mental and psychological fitness, faculty and student preparedness for virtual education will be constraint exceptionally. In response to such threat of Covid-19, it is suggested by many scholars to incorporate health and lifestyle-related lessons in all branches of education; no matter arts, business, science or social sciences (Toquero, 2020).

Student participation today, tomorrow, be it offline or online, is a challenge. During the lockdown, faculties initially had a lot of dissonance towards student engagement. When the faculty began taking online classes, they were surprised to see the attendance of the students is many times higher than regular class sessions and it was almost 100\% attendance in some cases (Shenoy, Mahendra, \& Vijay, 2020). Many students found that a lecturer's online participation allows them to engage further when they have necessary logistic supports both for the faculty members and the students. If a lecturer gives immediate or at least regular input virtually, students become more inspired and their engagement in online increases (Sarker et al., 2019). 
Regarding the relationship between instructor and student, most students indicated that their expectations did not match and they wanted more positive, communicative and constructive answers from their instructors, which much of the time remained unfulfilled (Sarker et al., 2019). One of the main reasons for such mismatches is the time required to be devoted by the faculty members for online teaching. While students and teachers are being benefited from an unusual virtual educational setting as they participated in an integrated learning process, teachers' professional development in terms of time management for research is impaired by more hours of contact in online teaching (Flores \& Gago, 2020).

Earlier studies on technology adoption mainly discuss various programs, challenges and suggestions for implementing e-learning in Bangladesh to ensure successful and highquality teaching and learning. In recent years, the usage of social media such as learning feedback systems in teaching and learning has become quite widespread due to its immersive style of training, which encourages and accommodates the needs of the learner (Islam et al., 2016). Many stakeholders appreciate the technical and logistical advantages of online courses as they offer flexibility, convenience and ease to the learners. Students may not necessarily need to attend a pre-scheduled lecture in the classroom that allows them freedom and choice and saves time and money on campus travel (Bower et al., 2015).

\section{Research framework and hypotheses development}

The research framework is proposed based on the relevant literature of online learning management. It is constructed on three crucial dimensions of technology-based distance learning called faculty readiness, student readiness and intention to adopt the technology.

Faculties must get ready to take virtual classes with the surge in the distance learning demand (Martin et al., 2019). Some conventional pedagogy users are new to online instruction and lack structured education about how to teach online effectively (Gülbahar \& Adnan, 2020; Kyei-Blankson, Ntuli, \& Blankson, 2019), but they were required to transform, build and introduce online learning (Cutri \& Whiting, 2018; Rennie \& Morrison, 2013). Faculty readiness is typically characterized by faculty skills such as technology adoption and organizational culture (Garrison, Anderson, \& Archer, 2003; Gülbahar \& Adnan, 2020). In responding to the question of what encompasses quality of teaching for faculty members of universities when excellence in virtual learning is needed or necessary to be developed, Cutri \& Mena (2020) argued that the implementation of a quality virtual learning is a crucial commitment to acquire new skillsets and teaching pedagogy. Thus, cultural transition and better time management along with psychological preparedness of faculties are essential to consider while designing a successful online learning system (Adnan, 2018; Bussmann et al., 2017; Cutri \& Mena, 2020). The study, thus, includes faculty readiness to examine its importance for virtual learning in the research framework, mostly keeping Bangladesh and other developing countries in mind.

Student readiness includes psychological preparedness, skills for collaborative learning and technology application capabilities (Khalifeh et al., 2020). Motivation to participate in virtual classes has been shown as a crucial factor that plays a significant role in the successful involvement of students in virtual learning, among various psychological issues (Järvelä, Volet, \& Järvenoja, 2010; Renninger et al., 2011). We followed the principle of motivation introduced by Deci \& Ryan (1985), in which an individual is defined as a 
motivated individual that finds drive or incentive to perform (Ryan \& Deci, 2000). Research indicates that students with strong motivation exhibit better success (Li, Lee, \& Solmon, 2005), improved capacity to deal with uncertainty (Ryan, Connell, \& Grolnick, 1992), and commitment in technology (Ryan \& Deci, 2000). Interpersonal and intrapersonal capabilities provide skills for collaborative learning. The essential qualities that a student needs for becoming successful in virtual educational systems are skills such as collaboration, conflict resolution and creative thinking (Xiong, So, \& Toh, 2015). Selfefficacy is thought to be one of the most relevant intrapersonal competencies, according to Khalifeh and others (2020). Technology-based self-efficacy is s element that can affect the technology readiness of students. Self-efficacy is commonly characterized as the personal assessment of students of their potential to excel in the execution of a specific task or skill (Zimmerman, 2000). Besides, scholars consider other powerful influences, such as device availability, and the ability to manage technology as the elements of technological readiness of students (Nami \& Vaezi, 2018).

The adoption of technology is characterized by one's intention to embrace it (Ajzen, Nichols, \& Driver, 1995; Fishbein, 1980). Intention to adopt technology for virtual learning (IATV) is motivated by the factors like the enthusiasm of faculty and students to learn a new thing, the level of interest they have on technology and enjoyment of using technology for teaching and learning (Mtebe \& Raisamo, 2014). According to Compeau \& Higgins (1995), once individuals experience technology and find a positive outcome, they form a constructive opinion towards it. Earlier studies have identified many factors that affect the intention to use new technology (Agarwal \& Parasad, 1999; Davis, 1989). The concept of IATV includes but not limited to the attitudes of users towards the use of technology in education, pedagogical values and self-efficacy (Celik \& Yesilyurt, 2013). $\mathrm{Li}, \mathrm{Li}, \&$ Franklin (2016) analyzed four aspects of IATV including technology self-efficacy (TS), attitudes toward technology (ATT), perceived ease of use of technology (PEUT), and perceived barriers of technology adoption (PBTA). Their results indicated that TS, ATT, and PEUT were significant in predicting IATV, whereas PBTA was found insignificant to predict IATV.

\subsection{Faculty readiness hypotheses}

As the number of online courses offered grows, it is becoming critical for the faculty to be trained to teach online (Martin et al., 2019). Given that a substantial number of instructors are unexpectedly asked to transfer their classes to an entirely electronic world, it is necessary to take stock of the tools they have exposure and how they have accessed (Brooks \& Grajek, 2020). Hence, examining faculty readiness based on the value of different skills and knowledge for their online teaching is crucial. In their study, Denis and others (2004) found faculty preparedness and a strong relationship between instructors and students most vital (Martin et al., 2019). Based on the literature, faculty readiness can be considered as a crucial factor for the adoption of technology for the higher education system. So, the hypotheses to be tested are as follows.

- Hypothesis 1: There is a significant impact of faculty readiness on IATV.

- Hypothesis 2: Faculty readiness has a significant impact on AVC.

\subsection{Student readiness hypotheses}

Students must make adjustments and exert influence over their active learning in terms of speed, scope and exposure of the subject, the form of media accessed and time spent for 
study for the success in virtual learning. Students' learning control aspect often becomes an essential part of their readiness (Stansfield, McLellan, \& Connolly, 2004). Students are also one of the main factors within universities when introducing online learning programs. Hence, it is necessary to know the degree of readiness of the learners to be able to develop stable and prosperous e-learning programs (Ünal, Alır, \& Soydal, 2014). As discussed, the hypothesis to be tested regarding student readiness as a critical factor towards technology adoption in the field of higher education is given below.

- Hypothesis 3: There is a significant impact of student readiness on IATV.

- Hypothesis 4: Student readiness has a significant impact on AVC.

\subsection{Mediating hypotheses: Intention to adopt technology}

Despite the continued use of mediation in research, PLS-SEM studies frequently do not consider mediation effects in their predictions. They, therefore, often do not examine the importance of specific mediator(s) in structural models (Hair et al., 2017). In many cases, scholars concentrate on straight forward interactions and ignore the impact of mediation though the mediating effect can bring the appropriate model for explaining a phenomenon. Hence, the mediating effect of intention to accept technology for virtual learning adoption is a prime concern of this study. Virtual or distance learning refers to the provision of learning to students at any time or anywhere through digital network devices, such as smartphones, laptops and desktop computers (Wang, Wu, \& Wang, 2009). As per Teo (2010) and Swanson (1988), recognizing the purpose of users to utilize technologies is one of the most challenging issues for researchers mostly in the information sector. On being successful teachers through adopting technology should be inclined to adapt their role in education (Hardy, 1998). A lecturer who perceives the usage of technology has a beneficial effect on teaching is more inclined to utilize it (Mitra et al., 1999). Researches on mediating effect of different factors such as liking, online interaction, and techno-stress on technology-based education have been found in various studies (Chang \& Chen, 2020; Joo, Lim, \& Kim, 2016). Again, studies in different contexts have used intention to adopt technology as a mediator. Hence, the mediating effect hypotheses for the study are as follows.

- Hypothesis 5: There is a significant impact of IATV on AVC.

- Hypothesis 6: IATV has a significant mediating effect on the relationship between FR and AVC.

- Hypothesis 7: IATV has a significant mediating effect on the relationship between SR and AVC.

Based on the above literature and hypotheses, the following research framework is proposed. 


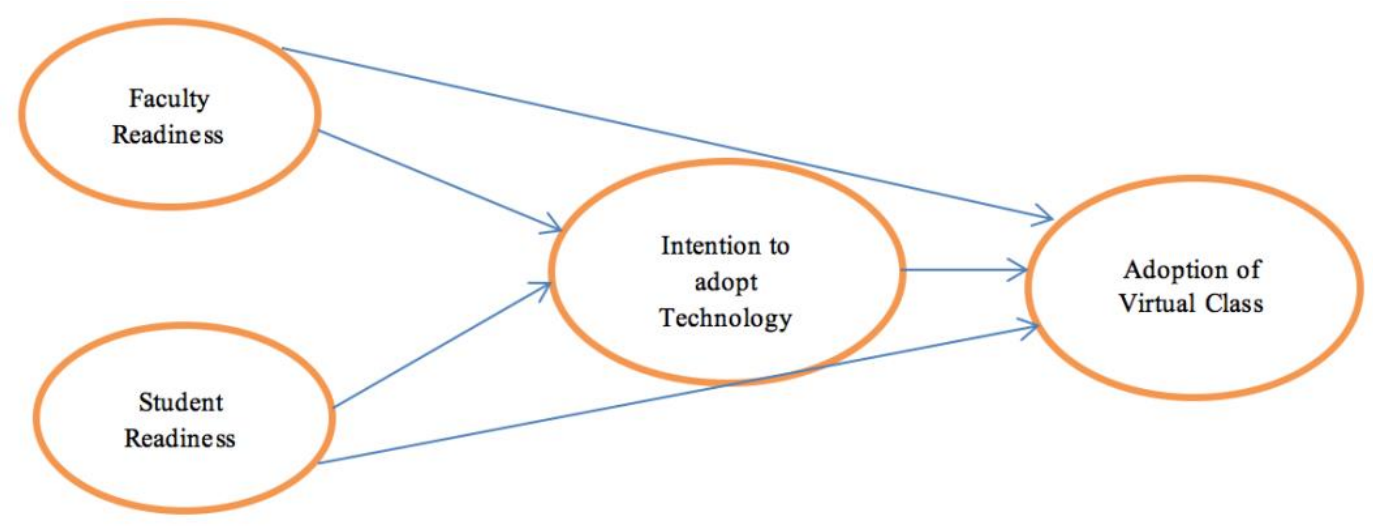

Figure 1. Research framework

Note: Elaborated by the author.

\section{Methodology}

This research is based on a quantitative method of analysis to examine the factors influencing virtual class adoption with special consideration of technology adoption intention as a mediator. This study followed the deductive approach as it is related to "developing some existing theories based concept (or hypothesis), and then constructing a testing method to support the validity" (Wilson, 2010). The analysis section is comprised of two parts. First, the measurement model (MM) was evaluated to ensure the reliability, validity and acceptability of the research. A Structural Equation Model (SEM) is proposed in the second part to assess the impact of faculty and student readiness on the adoption of virtual class considering the mediating effect of stakeholders' intent towards embracing technology for higher education in Bangladesh.

\section{Variable measurement}

The conceptual model of this study involves five direct and two indirect relations among the four variables. Two antecedents called faculty readiness (FR), and student readiness (SR) have been evaluated to find the direct impact of those on the intention to adopt the technology for virtual classes (IATV) and adoption of virtual classes (AVC). Again, the direct effect of IATV on AVC is examined. The indirect mediating effect of IATV on the relationship between FR and AVC, SR and AVC is also measured. FR is explored with three items, while SR includes four statements. There are three statements for IATV and AVC each. The hypotheses are examined with collected data using a Likert scale consisting of five points. The scale consists of a level of responses where ' 1 ' represents 'strongly disagree' and continues till ' 5 ' representing 'strongly agree'. The items in each construct, along with the source literature, are included in Table 1.

\section{Research data}

The data for this research were obtained from the students and faculty members of various private and public universities in Bangladesh. Primary information is always ideal for the analysis of this kind when the issue is entirely new, and secondary data is hardly sufficient to study a concern. Since Covid-19 is the latest issue, the preparation of the educational sector to cope with this circumstance is quite elusive. Therefore, to evaluate the factors influencing the adoption of virtual learning in Bangladesh amid the Covid-19 pandemic, this study is conducted using primary data. 
Table 1. Constructs, items and sources

\begin{tabular}{|c|c|c|c|}
\hline CONSTRUCT & & ITEM & SOURCE \\
\hline \multirow{3}{*}{$\begin{array}{l}\text { Faculty } \\
\text { readiness }\end{array}$} & FR 1 & $\begin{array}{l}\text { Faculty members are trained and } \\
\text { psychologically prepared for virtual } \\
\text { teaching. }\end{array}$ & \multirow{3}{*}{$\begin{array}{l}\text { Adnan, 2018; Tabata } \\
\text { and Johnsrud (2008); } \\
\text { Martin and others } \\
\text { (2019). }\end{array}$} \\
\hline & $\mathrm{FR} 2$ & $\begin{array}{l}\text { Faculty members are ready to adopt the } \\
\text { cultural transformation and to use an } \\
\text { audio-visual live stream of instructions } \\
\text { for virtual teaching. }\end{array}$ & \\
\hline & FR3 & $\begin{array}{l}\text { Faculty members take the help of various } \\
\text { equipment, devices and software for } \\
\text { making students better understand. }\end{array}$ & \\
\hline \multirow{4}{*}{$\begin{array}{l}\text { Student } \\
\text { readiness }\end{array}$} & SR 1 & $\begin{array}{l}\text { Students are technologically capable of } \\
\text { handling the required devices for virtual } \\
\text { classes. }\end{array}$ & \multirow{4}{*}{$\begin{array}{l}\text { Khalifeh and others } \\
\text { (2020); Stansfield, } \\
\text { McLellan and } \\
\text { Connolly (2004). }\end{array}$} \\
\hline & $\mathrm{SR} 2$ & $\begin{array}{l}\text { Students' understanding and their skills } \\
\text { for collaborative online learning are } \\
\text { satisfactory. }\end{array}$ & \\
\hline & SR3 & $\begin{array}{l}\text { Students are ready to ensure audio- } \\
\text { visual presence while attending virtual } \\
\text { classes. }\end{array}$ & \\
\hline & $\mathrm{SR} 4$ & $\begin{array}{l}\text { Students are psychologically motivated } \\
\text { to interact with the instructors in } \\
\text { virtual classes. }\end{array}$ & \\
\hline \multirow{3}{*}{$\begin{array}{l}\text { Intention to } \\
\text { adopt } \\
\text { technology }\end{array}$} & IATV 1 & $\begin{array}{l}\text { I am interested in using technology for } \\
\text { my education. }\end{array}$ & \multirow{3}{*}{$\begin{array}{l}\text { Mtebe and Raisamo } \\
(2014) .\end{array}$} \\
\hline & IATV2 & $\begin{array}{l}\text { Using technology for higher education is } \\
\text { enjoyable for me. }\end{array}$ & \\
\hline & IATV3 & $\begin{array}{l}\text { I am enthusiastic about using technology } \\
\text { and participating in virtual classes even } \\
\text { after the Covid-19 period. }\end{array}$ & \\
\hline \multirow{3}{*}{$\begin{array}{l}\text { Adoption of } \\
\text { online classes }\end{array}$} & $\mathrm{AOC} 1$ & I participate in virtual classes regularly. & \multirow{3}{*}{ Frydenberg (2007). } \\
\hline & $\mathrm{AOC} 2$ & $\begin{array}{l}\text { I like the virtual class, and I learn a lot } \\
\text { from it. }\end{array}$ & \\
\hline & AOC3 & $\begin{array}{l}\text { I find the virtual class useful, and I would } \\
\text { like to continue it in the future. }\end{array}$ & \\
\hline
\end{tabular}

Note: Elaborated by the author.

\section{Data collection procedure and period}

For understanding virtual learning adoption, a closed-ended questionnaire was constructed to assess and predict the effect of the explanatory variables on IATV and AVC. An online survey was performed using a questionnaire utilizing Google form. The face-to-face survey is not that convenient to conduct in this pandemic scenario of Covid19 , and that is the reason the online survey is better and safer for both respondents and researchers. It also allowed faculty and students from many of the country's universities to be accessed. Besides, two educationalists, one teacher and one student interested in online education, took part in interviews over the telephone, which ensured the applicability of the questionnaire. The survey link of Google form was sent to the participants using email and social media apps. The survey through Google form facilitated the process of gathering data from diverse participants from all over Bangladesh to receive required responses. The survey was launched on $24^{\text {th }}$ July 2020, and decaled closed on $12^{\text {th }}$ August 2020. Thus, the survey period includes 20 days for responses. 
Sample size

Students and faculty members are the respondents for this analysis systematically selected from thirty different universities in Bangladesh. To ensure data independence, each university requires at least twelve respondents from diverse disciplines such as science and engineering, social science, humanities and business. For this analysis, the sample size is 398 , which meets the criteria for such studies with a minimum of 384 samples for a population size of 1.00 .000 or more (Krejcie \& Morgan, 1970).

\section{Participants' demographic characteristics}

The faculty and students of universities in Bangladesh comprise the research population. The sample includes ninety-six (96) faculties (24.12\%) and three hundred two (302) students $(75.88 \%)$. Around $45 \%$ of the respondents are female, and $55 \%$ are male from various Bangladeshi private and public universities. Two Hundred Seventy-Eight (279) participants of this study (70\%) are from private universities while the rest of them (30\%) are from public universities and the National University of Bangladesh. The reasons for having more participants from private universities are two. First, the number of private universities that started academic activities is 98 (68.06\%) (University Grants Commission of Bangladesh [UGCB], 2020) whereas, the number of public universities in Bangladesh is 46 (31.94\%) (UGCB, 2020a). Second, most of the private universities are situated in the city areas and the students are also from cities with a better access and exposure to the internet while the public universities are scattered throughout the country and many of them stay in the rural areas, especially during the pandemic. As the survey is administrated mainly over the internet in Google form, better access to the internet is import to reach the respondents.

The respondents from private universities are well ahead of adopting virtual classes, as around $94 \%$ of them have already experienced online learning fully or partially. On the other hand, the respondents of public universities have shown a disappointing picture as only $12 \%$ of them have occasionally participated in virtual classes with no official declaration of distance learning from those universities. The average participation rate of the respondents in the virtual class is around $64 \%$.

Many of the respondents have changed their living areas during official closures of educational institutions since they do not need to attend physical classes. The respondents have been asked about their living areas from which they take part in virtual classes. It is discovered that nearly $72 \%$ of respondents attended classes from urban areas and $28 \%$ from rural regions. Again, the rate of attending virtual classes from the respondents of the metropolitan area is around $83 \%$. The rate is about $35 \%$ of the participants in the rural area.

The statistics in Table 2 shows clear discrimination between the stakeholders of public and private universities as well as the rural and urban areas regarding the exposures to the virtual learning amid Covid-19. Such discrimination is a symbol of social imbalance that will lead to severe consequences if the proper initiative is not taken immediately to eradicate this social injustice. 
Table 2. Demographic statistics

\begin{tabular}{|c|c|c|c|}
\hline PARAMETER & $\begin{array}{c}\text { PRIVATE } \\
\text { UNIVERSITIES }\end{array}$ & $\begin{array}{c}\text { PUBLIC } \\
\text { UNIVERSITIES }\end{array}$ & TOTAL \\
\hline Number of participants & 279 & 119 & 398 \\
\hline Number of Faculty members out of 398 & 73 & 23 & 96 \\
\hline Number of students out of 398 & 204 & 98 & 302 \\
\hline Number of female participants out of 398 & 131 & 48 & 179 \\
\hline Number of male participants out of 398 & 149 & 70 & 219 \\
\hline Number of urban participants out of 398 & 205 & 82 & 287 \\
\hline Number of rural participants out of 398 & 74 & 37 & 111 \\
\hline $\begin{array}{l}\text { Number of urban participants with virtual class } \\
\text { experiences out of } 287\end{array}$ & 227 & 11 & 238 \\
\hline $\begin{array}{l}\text { Number of rural participants with virtual class } \\
\text { experiences out of } 111\end{array}$ & 36 & 3 & 39 \\
\hline $\begin{array}{l}\text { Number of private university participants with } \\
\text { virtual class experiences out of } 279\end{array}$ & 263 & $\mathrm{~N} / \mathrm{A}$ & 263 \\
\hline $\begin{array}{l}\text { Number of public university participants with } \\
\text { virtual class experiences out of } 119\end{array}$ & $\mathrm{~N} / \mathrm{A}$ & 14 & 14 \\
\hline
\end{tabular}

Note: Elaborated by the author.

\section{Assessment of measurement model (Outer model)}

According to Hair and others (2016), the outer model in Partial Least Squares Structural Equation Modeling (PLS-SEM) is an element of a path model that holds the indicators and their relationship with the latent variables. The measurement model should be assessed based on internal consistency, convergent validity and discriminant validity.

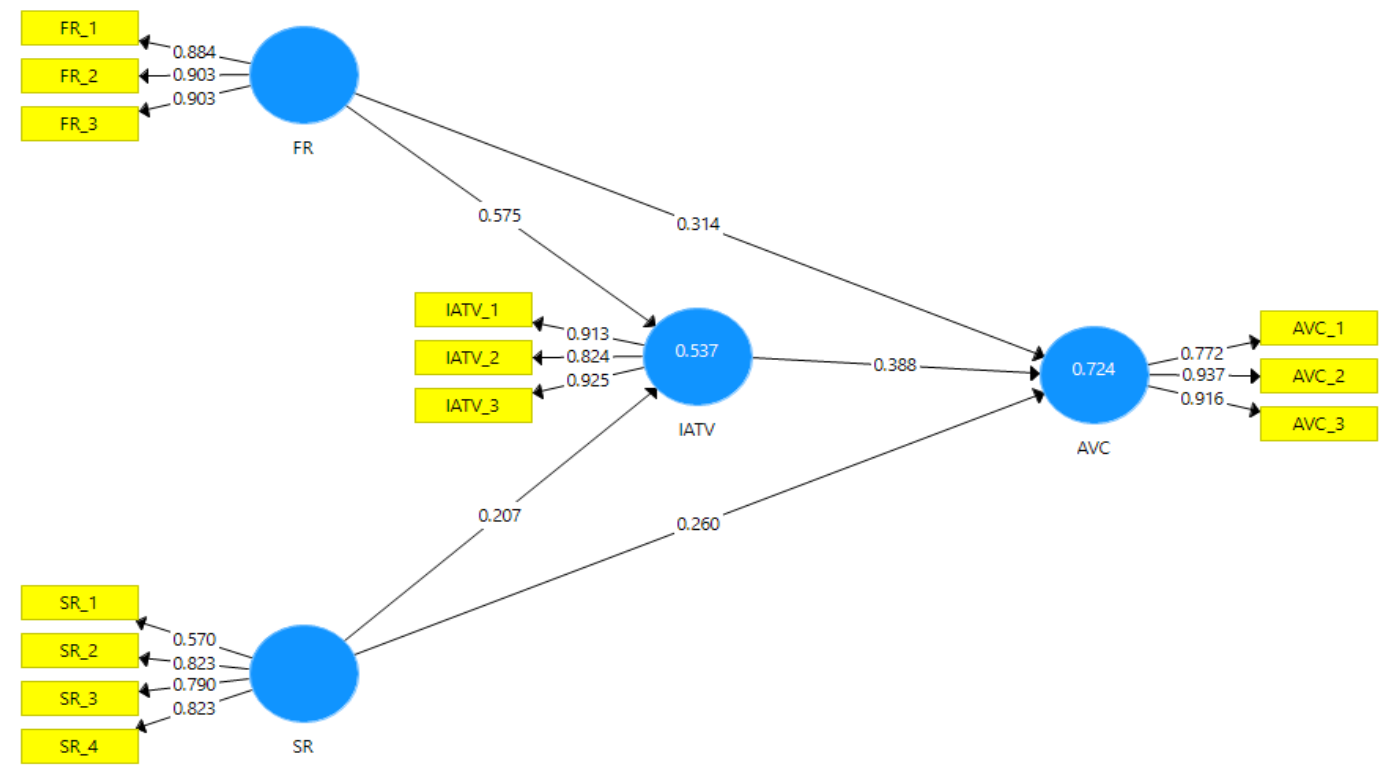

Figure 2. Measurement model

Note: Elaborated by the author.

\section{Indicator reliability}

The size of the outer loading is usually referred to as indicator reliability (Hair et al., 2016). SmartPLS 3.0 was used to evaluate the loading, composite reliability and average variance extracted (AVE). Traditionally, 0.70 should be the minimum cutoff value for individual item loading (Hair et al., 2016; Henseler et al., 2010) as higher outer loadings 
indicate that the indicators in a construct are much in common that has been captured by the construct. Vinzi, Trinchera and Amato (2010) has suggested that 0.5 should be the minimum value for outer loading, and AVE should be above 0.5. To improve the quality of data, Hair and others (2016) proposed removal of the indicator with outer loadings below 0.5 when the deletion of the indicator leads to boosting of AVE or composite reliability value above the threshold level of 0.5. Therefore, all the items are ensuring the reliability of the indicators of this study (Table 3) as per relevant literature.

Table 3. Reliability and validity measures

\begin{tabular}{|c|c|c|c|c|c|}
\hline CONSTRUCT & ITEMS & LOADINGS & $\begin{array}{c}\text { CRONBACH'S } \\
\text { ALPHA }\end{array}$ & $\begin{array}{l}\text { COMPOSITE } \\
\text { RELIABILITY }\end{array}$ & AVE \\
\hline \multirow{3}{*}{ Faculty readiness } & FR1 & 0.884 & \multirow{3}{*}{0.879} & \multirow{3}{*}{0.925} & \multirow{3}{*}{0.804} \\
\hline & $\mathrm{FR} 2$ & 0.903 & & & \\
\hline & FR3 & 0.903 & & & \\
\hline \multirow{4}{*}{ Student readiness } & SR 1 & 0.570 & \multirow{4}{*}{0.754} & \multirow{4}{*}{0.842} & \multirow{4}{*}{0.576} \\
\hline & $\mathrm{SR} 2$ & 0.823 & & & \\
\hline & SR3 & 0.790 & & & \\
\hline & $\mathrm{SR} 4$ & 0.823 & & & \\
\hline \multirow{3}{*}{$\begin{array}{l}\text { Intention to adopt technology } \\
\text { for virtual classes }\end{array}$} & IATV1 & 0.913 & \multirow{3}{*}{0.866} & \multirow{3}{*}{0.918} & \multirow{3}{*}{0.789} \\
\hline & IATV 1 & 0.824 & & & \\
\hline & IATV 1 & 0.925 & & & \\
\hline \multirow{3}{*}{ Adoption of virtual classes } & AVC1 & 0.772 & \multirow{3}{*}{0.849} & \multirow{3}{*}{0.910} & \multirow{3}{*}{0.771} \\
\hline & $\mathrm{AVC} 2$ & 0.937 & & & \\
\hline & AVC3 & 0.916 & & & \\
\hline
\end{tabular}

Note: Elaborated by the author.

\section{Internal consistency reliability and convergent validity}

Internal Consistency reliability refers to a form of reliability used to estimate whether the items that are being used to measure a construct are similar in scores (Hair et al., 2016). Based on Nunnally \& Bernstein (1994)'s criteria for reliability, Hair and others (2016) suggest the value of composite reliability (CRI) to be greater than 0.70 with a slack of $0.60-0.70$ as the acceptable range in exploratory research. The CRI for all the latent variables in this study was found to be higher than 0.7 hence, meeting and exceeding the minimum cut off value suggested by various literature (Fornel \& Larcker, 1981; Hair et al., 2016; Nunally \& Bernstein, 1994). Cronbach's alpha is also used as the measure of internal consistency reliability which provides an indication of reliability based on the intercorrelations of the indicators of the observed variable. According to Liouville and Bayad (1998), Sureshchandar, Rajendran and Anantharaman (2002) and Hair and others (1998), the acceptable level of Cronbach's alpha is 0.7 while Cronbach's alpha over 0.80 indicates a high reliability of the study data. Similarly, Nunnaly and Bernstein (1978) has suggested that the alpha value of 0.7 or above indicates high reliability. All the alpha values of this study are higher than 0.7 (Table 3) ensuring the criteria for internal consistency for this research.

Convergent validity is the degree of agreement among the items in measuring a specific concept. The outer loadings of the indicators and the AVE are usually considered by researchers to establish convergent validity based on Hair and others (2016), Fornell and Larcker (1981) criteria. Hair and others (2016) further argued that when the factor loading of all the items is higher than 0.5 while no loading of any item from the other latent variables has more loading than the one which is being measured, convergent 
validity is obtained. The values in table 4 satisfy the criteria for convergent validity as per Hair and others (2016).

\section{Discriminant validity}

According to Hair and others (2016), discriminant validity explains the extent to which one latent variable is uniquely distinct from the other variables by empirical standards. Traditionally, there are two widely used measures of discriminant validity. The first approach is to evaluate cross-loadings. To be specific, the outer loading of an indicator on the associated latent variable must have a greater value than any of its cross-loadings on other variables (Hair et al., 2016). The second approach of assessing discriminant validity is Fornell-Larcker criterion which compares the square root of the average variance extracted value with the construct correlations. The square root of each latent variable's AVE should be greater than the highest correlation it has with any other variable. Venkatesh \& Morris (2000), in line with Hair and others (2016) suggest that the square root of average variance extracted value for every latent variable must be larger than the value of correlations with another variable. The cross-loading in table 4 and FornellLarcker scores in Table 5 satisfy the required measures since no indicator exhibited higher loading in any other construct other than its mother construct according to Chin's (1998) and Hair and others (2016).

Table 4. Cross loadings

\begin{tabular}{lccll}
\hline & FR & SR & IATV & AVC \\
\hline FR_1 & $\mathbf{0 . 8 8 4}$ & 0.630 & 0.594 & 0.661 \\
FR_2 & $\mathbf{0 . 9 0 3}$ & 0.631 & 0.622 & 0.681 \\
FR_3 & $\mathbf{0 . 9 0 3}$ & 0.583 & 0.706 & 0.726 \\
SR_1 & 0.322 & $\mathbf{0 . 5 7 0}$ & 0.261 & 0.355 \\
SR_2 & 0.611 & $\mathbf{0 . 8 2 3}$ & 0.604 & 0.666 \\
SR_3 & 0.482 & $\mathbf{0 . 7 9 0}$ & 0.387 & 0.502 \\
SR_4 & 0.594 & $\mathbf{0 . 8 2 3}$ & 0.485 & 0.559 \\
IATV_1 & 0.689 & 0.617 & $\mathbf{0 . 9 1 3}$ & 0.735 \\
IATV_2 & 0.566 & 0.407 & $\mathbf{0 . 8 2 4}$ & 0.585 \\
IATV_3 & 0.646 & 0.554 & $\mathbf{0 . 9 2 5}$ & 0.715 \\
AVC_1 & 0.549 & 0.615 & 0.498 & $\mathbf{0 . 7 7 2}$ \\
AVC_2 & 0.741 & 0.646 & 0.749 & $\mathbf{0 . 9 3 7}$ \\
AVC_3 & 0.721 & 0.612 & 0.751 & $\mathbf{0 . 9 1 6}$ \\
\hline FR & $\mathbf{0 . 8 9 7}$ & & & \\
SR & 0.684 & $\mathbf{0 . 7 5 9}$ & & \\
IATV & 0.717 & 0.601 & $\mathbf{0 . 8 8 8}$ & \\
AVC & 0.770 & 0.708 & 0.769 & $\mathbf{0 . 8 7 8}$ \\
\hline Note: Elabo & & &
\end{tabular}

Note: Elaborated by the author.

Though Fornell-Larcker criterion is a valid measure of discriminant validity, it cannot provide an additional theoretical rationale. Hence, scholars have suggested a method called Heterotrait-Monotrait (HTMT) Ratio to test the discriminant validity (Henseler, Ringle, \& Sarstedt, 2015). This approach requires the comparison of a fixed threshold value with the correlations between the constructs. Teo, Lee and Chai (2008) suggested a threshold value of 0.90 to ensure an acceptable HTMT ratio for discriminant validity. Table 6 indicates that all the HTMT ratios are below 0.90. It is therefore concluded that all the constructs of the analysis are distinct from each other and have obtained the discriminant validity. 
Table 6. Heterotrait-monotrait ratio (HTMT)

\begin{tabular}{lllll}
\hline & FR & SR & IATV & AVC \\
\hline FR & & & & \\
SR & 0.817 & & & \\
IATV & 0.815 & 0.699 & & \\
AVC & 0.884 & 0.866 & 0.880 & \\
\hline
\end{tabular}

Note: Elaborated by the author.

\section{Assessment of Structural Model (Inner Model)}

The inner model in PLS-SEM illustrates the theoretical elements of the path model by including the latent variables and their path relationships (Hair et al., 2016). The primary criteria for evaluating the structural model or the inner model in PLS-SEM are the level of the $\mathrm{R}^{2}$ values, the $\mathrm{f}^{2}$ effect size, the predictive relevance $\mathrm{Q}^{2}$ and relevance of the path coefficients (Hair et al., 2016). The coefficient of determination $\left(\mathrm{R}^{2}\right)$ is used in assessing the variance in the outcome variable by the predictors (Chin, 1998). Additionally, the effect sizes indicated by $\mathrm{f}^{2}$ of each independent variable were estimated and evaluated following Cohen's criteria (1988). The bootstrapping procedure was used to determine the predictive capability indicated by $Q^{2}$ (Chin, 1998; Fornell \& Cha, 1994; Hair et al., 2011; Henseler, Ringle, \& Sinkovics, 2009). Finally, the obtained path coefficients represent the relationships among the variables that have been hypothesized, and the standardized value of such path coefficients range from -1 to +1 (Hair et al., 2016).

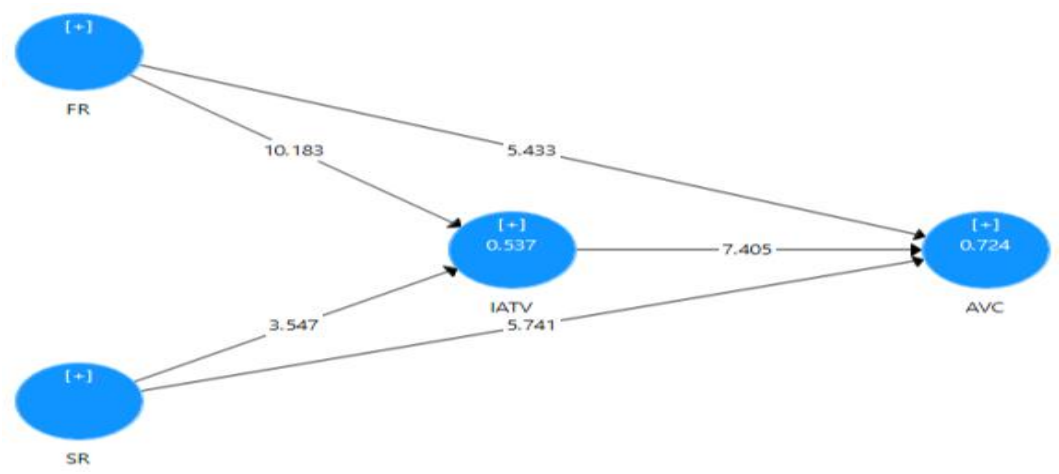

Figure 3. Structural model

Note: Elaborated by the author.

Coefficient of determination (R2)

Coefficient of determination is a measure that indicates the predictive accuracy of a model. The coefficients represent the combined effects of independent variables on the dependent variable. The value of $\mathrm{R}^{2}$ is considered satisfactory if it goes beyond $15 \%$ (Falk and Miller, 1992). On the other hand, three levels of structural model quality have been recommended by Cohen (1988) and Chin (1998a); namely: weak (0.02 and 0.19), moderate (0.13 and 0.33) and substantial (0.26 and 0.67). The $\mathrm{R}^{2}$ scores for both of the variables called AVC and IATVC (Table 7) are found substantial in this study. 
Table 7. R Square

\begin{tabular}{lll}
\hline Dependent Variable & R Square & R Square Adjusted \\
\hline AVC & 0.724 & 0.722 \\
IATV & 0.537 & 0.535 \\
\hline
\end{tabular}

Note: Elaborated by the author.

\subsection{Effect size (f2) of the main effect model}

Effect Size $\left(\mathrm{f}^{2}\right)$ measures the change in $\mathrm{R}^{2}$ due to the removal of a specific independent variable from the model. It indicates whether the removed variable has a significant effect on the dependent variable (Hair et al., 2016; Callaghan et al., 2007). The effect sizes are considered large, medium and small according to the values of $0.350,0.150$ and 0.020 , respectively of the exogenous latent variable (Cohen, 1988). Chin, Marcolin, \& Newsted (2003) has argued that even a small effect size can be considered.

Table 8. Result of F-Square

\begin{tabular}{cccc}
\hline ENDOGENOUS CONSTRUCTS EXOGENOUS CONSTRUCTS & F2 & EFFECT SIZE \\
\hline \multirow{2}{*}{ AVC } & FR & 0.157 & Medium \\
& SR & 0.125 & Small \\
\hline \multirow{2}{*}{ IATV } & FR & 0.381 & Large \\
& SR & 0.049 & Small \\
\hline AVC & IATV & 0.252 & Medium \\
\hline
\end{tabular}

Note: Elaborated by the author.

As per the arguments of Cohen (1988), table 8 ensures that faculty readiness has a large and a medium effect on IATV and AVC, respectively. Student readiness is having a small impact both on IATV and AVC. Finally, the mediator IATV has a medium impact on AVC.

\subsection{Predictive relevance (Q2)}

Stone-Geisser's Q2 value needs to be evaluated as a criterion of predictive accuracy, along with the evaluation of the magnitude of the $\mathrm{R}^{2}$ values (Geisser, 1974; Stone, 1974). The blindfolding procedure was used to test the Q2 of cross-validated redundancy and crossvalidated communality. According to Hair and others (2016), Q2 values greater than zero for a specific reflective dependent variable in a structural model, indicate the predictive relevance of that said variable of the path model. Osborne, Costello, \& Kellow (2008) suggest the communality above 0.4 are acceptable. However, Child (2006) indicates that the value of communality below 0.2 should be removed.

Table 9. Construct cross validated communality

\begin{tabular}{lccc}
\hline & SSO & SSE & $\mathbf{Q}^{\mathbf{2}}(=\mathbf{1 - S S E} / \mathbf{S S O})$ \\
\hline AVC & 1194.000 & 559.982 & 0.531 \\
FR & 1194.000 & 507.834 & 0.575 \\
IATV & 1194.000 & 533.089 & 0.554 \\
SR & 1592.000 & 1089.662 & 0.436 \\
\hline
\end{tabular}

Note: Elaborated by the author. 


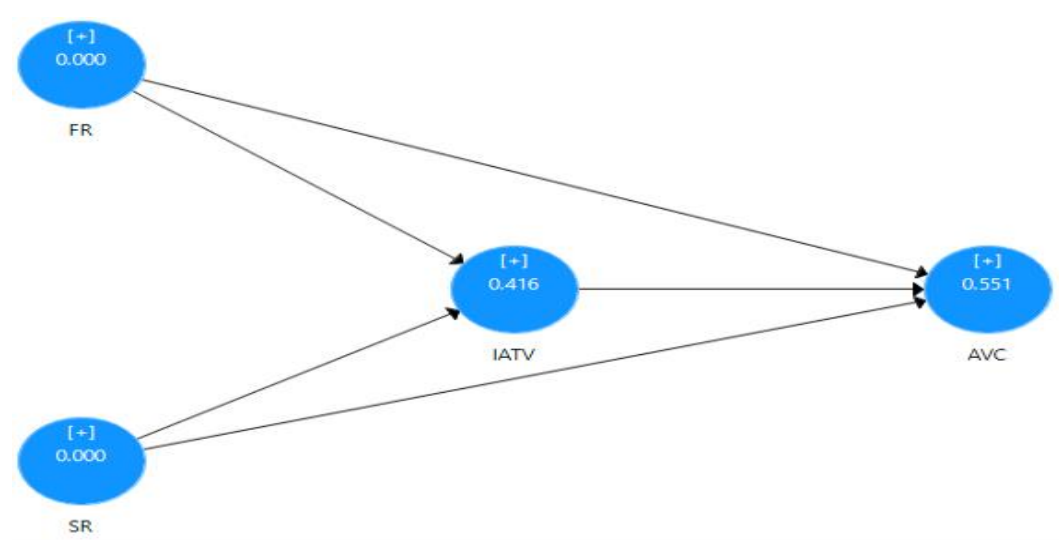

Figure 4. Blindfolding procedure

Note: Elaborated by the author.

Table 10. Construct cross validated redundancy

\begin{tabular}{lccc}
\hline & SSO & SSE & $\mathbf{Q}^{\mathbf{2}}(=\mathbf{1 - S S E} /$ SSO $)$ \\
\hline FR & 1194.000 & 1194.000 & \\
SR & 1592.000 & 1592.000 & \\
IATV & 1194.000 & 696.760 & 0.416 \\
AVC & 1194.000 & 536.227 & 0.551 \\
\hline
\end{tabular}

Note: Elaborated by the author.

The $\mathrm{Q}^{2}$ value was measured using a blindfolding procedure and all the $\mathrm{Q}^{2}$ values satisfy the required criteria as per Child (2006); Hair and others (2016) and Osborne, Costello, \& Kellow (2008).

\section{Results}

\subsection{Results of direct hypothesis}

There are seven hypotheses in this study. Among the hypotheses, five (5) are direct and two (2) are mediating. The PLS bootstrapping was run to obtain the p-values with 5000 bootstrap samples. P-values were directly obtained from SmartPLS 3 based on a $5 \%$ level of significance as that is the acceptable level in social science research (Bickel, 2012; Cox \& Hinley, 1979; Tacq \& Tacq, 1997).

Table 11. Path coefficients (Direct effect).

\begin{tabular}{lcccccc}
\hline & $\begin{array}{c}\text { ORIGINAL } \\
\text { SAMPLE }(\mathbf{O})\end{array}$ & $\begin{array}{c}\text { SAMPLE } \\
\text { MEAN (M) }\end{array}$ & $\begin{array}{c}\text { SD } \\
(\text { STDEV })\end{array}$ & $\begin{array}{c}\text { T STATISTICS } \\
(\mid \mathbf{O} / \text { STDEV } \mid)\end{array}$ & P & HD \\
\hline FR -> IATV & 0.575 & 0.576 & 0.057 & 10.183 & 0.000 & $\mathrm{~S}$ \\
FR -> AVC & 0.314 & 0.315 & 0.058 & 5.433 & 0.000 & $\mathrm{~S}$ \\
SR -> IATV & 0.207 & 0.207 & 0.058 & 3.547 & 0.000 & $\mathrm{~S}$ \\
SR -> AVC & 0.260 & 0.260 & 0.045 & 5.741 & 0.000 & $\mathrm{~S}$ \\
IATV -> AVC & 0.388 & 0.387 & 0.052 & 7.405 & 0.000 & $\mathrm{~S}$ \\
\hline
\end{tabular}

Note: HD: Hypotheses Decision. S: Supported.

The values illustrated in table 11 confirm that the direct hypotheses concerning all the exogenous and endogenous variables were supported at a $5 \%$ significance level. The beta value $(\boldsymbol{\beta}=0.575)$ indicates a positive relationship between FR and IATV. Similarly, FR has a positive impact on AVC with a beta of 0.314 . Thus, hypothesis 1 and hypothesis 2 
are accepted. It is also important to mention that faculty readiness has the most influencing power in explaining the intention to adopt technology and adoption of virtual classes. Likewise, student readiness has a positive impact both on IATV and AVC with a beta value of 0.207 and 0.260 , respectively. Hence, hypothesis 3 and hypothesis 4 are also accepted. Finally, IATV has a significant positive impact on the adoption of virtual classes with a beta of 0.388 , indicating the acceptance of hypothesis 5 .

\subsection{Results of mediating hypotheses}

Bootstrapping is said to be a tool to illustrate mediating influence in PLS-SEM since it can be used with a small sample size as argued by Hair and others (2016). Preacher and Hayes's $(2004,2008)$ procedure can also be followed while evaluating mediation effects. If the indirect effect is significant, the mediating effect is said to exist. The latest research on mediation addresses two separate forms of mediations, absolute and partial mediation. In the case where the direct effect is not significant, but the indirect effect is significant, a full mediation is implied. On the other hand, partial mediation is ensured when both the direct and indirect effects are significant (Carrión, Nitzl, \& Roldán, 2017).

Table 12. Path coefficients (Mediation effect)

\begin{tabular}{lcccccc}
\hline & $\begin{array}{c}\text { ORIGINAL } \\
\text { SAMPLE }(\mathbf{O})\end{array}$ & $\begin{array}{c}\text { SAMPLE } \\
\text { MEAN }(\mathbf{M})\end{array}$ & $\begin{array}{c}\text { SD } \\
(\text { STDEV })\end{array}$ & $\begin{array}{c}\text { T STATISTICS } \\
(\mid \mathbf{O} / \text { STDEV } \mid)\end{array}$ & P & HD \\
\hline $\begin{array}{l}\text { FR }->\text { IATV } \rightarrow> \\
\text { AVC }\end{array}$ & 0.223 & 0.222 & 0.033 & 6.771 & 0.000 & $\mathrm{~S}$ \\
$\begin{array}{l}\text { SR }>\text { IATV } \rightarrow> \\
\text { AVC }\end{array}$ & 0.080 & 0.081 & 0.028 & 2.879 & 0.004 & $\mathrm{~S}$ \\
\hline
\end{tabular}

Note: Elaborated by the author.

The results in Table 12 show the mediating effect of IATV at $5 \%$ level of significance. Hence, it is evident that intention to adopt technology mediates the relationship between faculty readiness and adoption of virtual classes in Hypothesis 6 and student readiness and adoption of virtual classes in Hypothesis 7. Since both the direct effect (FR-> AVC) and the indirect effect (FR -> IATV $->$ AVC) for faculty readiness are significant, there is a partial mediation. Similarly, the direct effect (SR-> AVC) and the indirect effect (SR $>$ IATV $->$ AVC) for student readiness are significant which ensures partial mediation (See table 11 for direct effect and Table 12 for indirect effect for both FR and SR). Again, complementary and competitive mediating effects are the two subsections of partial mediation. When both the direct and indirect effects indicate the same direction (positive or negative), there is a complementary partial mediation. On the contrary, when the direct and indirect effects are in the opposite direction, the mediating effect is competitive (Baron \& Kenny, 1986). According to the argument of Carrión, Nitzl \& Roldán (2017) and Baron and Kenny (1986), the results in Table 11 and Table 12 ensure that the intention to adopt technology has a complementary partial mediating effect both on the relationship between faculty readiness and virtual class adoption and student readiness and adoption of the virtual class.

\section{Discussions}

The results have been analyzed and acknowledged as relevant, based on the conceptual model presented in this research. All the seven hypotheses related to faculty readiness (FR), student readiness (SR) and intention to adopt the technology (IATV) as a mediator for virtual class adoption (AVC) are accepted for the model. The $\mathrm{R}^{2}$ value of 0.724 is 
substantial as per Cohen (1988) indicating that FR and SR with the mediating effect of IATV can explain $72.4 \%$ variation in the adoption of online classes by the students and the faculty members.

The test of the hypotheses shows that FR has the largest effect on IATV and AVC with beta values of 0.575 and 0.314 , respectively. Both the IATV and AVC rely heavily on the instructors' willingness and readiness to adopt the technology. Proper training for teachers is, therefore, a must to persuade the students and the faculty to consider technology and virtual classes. Student readiness with beta values of 0.207 for IATV and 0.260 for AVC shows that the preparation of students to embrace technology is vital in shaping their intent towards virtual learning adoption amid Covid-19. Students need to be prepared with the requisite resources and mental capacity to ensure distance learning progress if we consider the full engagement of the students to be a crucial factor. The mindset of faculty and students is vital when technology-based virtual education is a matter of concern. If the stakeholders are mentally constrained to adopt technology, it becomes challenging to grab the benefits of using it. The results of the study ensure the importance of intention to adopt technology on AVC with a beta of 0.388. Besides, IATV has a partial complementary mediating effect on the relationship between faculty and student readiness and adoption of virtual classes. Overall, technology adoption for higher education for virtual learning depends on the issues like whether the faculty members are ready to accept it and take the lead to support the students in preparing themselves with logistics and mental support to allow the technology.

Policymakers, government and university officials should understand the strategic ramifications of this research model, and develop new approaches and strategies to promote the virtual learning platform by ensuring enabling elements to ease the whole system of online education. While several of Bangladesh's private universities have already started conducting classes online, it is hardly appropriate to public universities. It may then establish a gap between learners, and some can lag behind others. Similarly, the worst sufferers are the students from rural areas, and they may drop out due to the solvency problem. Institutions should take initiatives to bring changes and train their faculty to get ready to take online classes and influence students to accept the new education system. In particular, maintaining student and faculty readiness in terms of access to the internet and the availability of inexpensive devices is a must for the sustainability of technology-based higher education architecture.

\section{Research implications}

\subsection{Theoretical implication}

This research suggests two elements as the indicators to understand the acceptance of virtual class for higher education in Bangladesh. It also explains how the intention to adopt technology mediates the interaction between the exogenous and indigenous variables. Developing countries that are new to the online learning environment can also use the model suggested in this study to promote social justice by offering fair learning opportunities for everyone. This model differs from other related research where the readiness of the teachers and the readiness of the students are assessed separately to illustrate the acceptance of online education. For example, Tabata \& Johnsrud (2008) discussed the readiness of faculty, while Stansfield, McLellan \& Connolly (2004) identified the preparedness of students to understand the implementation of technology-based 
education. This study, however, offers a detailed model integrating the readiness of teachers with the readiness of students to explain the acceptance of virtual classes. Inclusion of the intention of the faculty and students to accept technology is a new dimension which ensures the theoretical contribution of this research. Hence, this paper has introduced a new approach to explain the implementation of virtual learning in the higher education sector to fill the literature gap on addressing the need for emergency education amid difficulties such as Covid-19 in a developing country.

\subsection{Practical implication}

Covid-19 has brought a very critical hurdle for Bangladesh's higher education sector. Because of this, the education system was facing a significant halt and universities had been suspended since March 17, 2020. In this crisis scenario, the conventional approach of teaching is truly impossible. On this backdrop, the best way to pursue higher education is to start virtual classes as soon as possible. A few private universities have already begun full-fledged online learning in Bangladesh, and many others have taken steps to introduce it. Unfortunately, the failure of the public universities in the official launching of virtual classes could create a big divide between the private and public university in Bangladesh. The implementation model suggested in this study has a critical realistic significance in the sense that Bangladesh's policymakers of academia, educationalists, government and university authorities should use it to figure the way out to step forward and prevent the education sector from getting worse. The entire country will face substantial failure until it launches the new virtual education system. This study, thus, provides essential insights into the introduction of technology-based online classes for higher education from the perspective of a developing country.

\subsection{Social implication}

Adoption of technology in the education sector in Bangladesh has already generated disparity between students from rural and urban areas, as well as private and public universities. As per the research findings, private universities have already started taking online classes and developing ideas to meet the demand and preserve credibility on the excellent conduct of virtual courses. On the opposite, the government-run public universities are still struggling to take a strategic decision and propose a comprehensive virtual education platform. Hence, the students of these educational institutions are not advancing in their academics. It, thereby, establishes a divide between the students and demonstrates a disparity in society. The social implications of such segregation are massive and may lead to civil instability and imbalance. Such a discriminatory education framework should be discussed forthwith. Policymakers in government and higher education stakeholders should take the required measures to ensure a sustainable higher education system that embarks all students without further delay regardless of their locality and the type of university they belong to. This research will play a critical role in offering valuable insights into the issues required for concentrating for the effective implementation of online education based on technology. Hence, the results of this research will help in policymaking for eliminating social injustice and disparity in the higher education system. 


\section{Conclusion and scope for future research}

\subsection{Conclusion}

This study aimed at explaining the faculty and student readiness in determining the online education adoption amid Covid-19. The mediating role of the technology adoption intention has been explored as well to adopt virtual learning as an aid to the higher education system for eliminating the discrimination between rural and urban areas and private and public universities in Bangladesh. A structural model is suggested based on a survey of primary data obtained from students and faculty members of different universities in Bangladesh. It can be inferred that Bangladesh's higher education system is partially able to adopt technology-based distance learning to cope with the pandemic crisis. The notable point is that most private universities have started offering virtual classes, faculties and students of such universities are ready with proper tools, computers, apps and creative methods of evaluation as they are trying hard to embrace the technology. Faculty and students have a strong desire to adopt virtual learning when the opportunities are available. However, many of the faculty and students are still not in a position to continue their education without such facilities. Overall, acceptance of virtual education during this crisis phase will turn into a blessing for the future development of the higher education sector in Bangladesh and other developing countries if adequately negotiated. If the aim is to adopt technology-based education framework for the higher education sector, all stakeholders need to work together to address the barriers. Institutions should help students and instructors with tools and equipment and provide with the necessary training for effective online teaching and learning. The government needs to ensure infrastructural support, especially in the rural areas and for the public universities, to eradicate all the constraints for ensuring social justice. Lastly, teachers need to inspire students and improve interaction with them online. Institutions, government and software vendors should work together to prevent technical breakdowns. Policymakers, educationalists, government and all stakeholders should take this virtual learning as an opportunity, and adopt creative ways to make this education system a successful endeavor.

\subsection{Limitations and scope for future research}

The primary data were gathered for this research electronically via Google form during a short time frame of around 20 days. Thus, this analysis did not reach all students who had no internet access during this period. Inclusion of those students may make such studies more detailed, with a clearer understanding of the challenges faced by this untapped group of people. Only the opinions of the students and teachers are the basis of this research. In future studies, the participation of other higher education stakeholders such as university officials, government agencies and policymakers may add various aspects. The research study spectrum is confined within the tertiary level of education. Consideration of primary and secondary level education is more or equally crucial for social balance. Thus, research may be conducted in such areas. Lastly, this paper explored and explained an adoption model for complete technology-based virtual learning. Hence, researchers can also study on the prospects of a blended learning system in Bangladesh, which might be the future of the higher education system for both developing and developed countries. 


\section{References}

Adnan, M. (2018). Professional development in the transition to online teaching: The voice of entrant online instructors. ReCALL, 30(1), 88-111.

https://doi.org/10.1017/S0958344017000106

Agarwal, R. \& Prasad, J. (1999). Are individual differences germane to the acceptance of new information technologies? Decision Sciences, 30(2), 361-391

https://doi.org/10.1111/j.1540-5915.1999.tbo1614.x

Ajzen, I., Nichols, A. J., \& Driver, B. L. (1995). Identifying salient beliefs about leisure activities: Frequency of elicitation versus response latency 1. Journal of Applied Social Psychology, 25(16), 1391-1410. https://doi.org/10.1111/j.1559-1816.1995.tbo2623.x

Allen, I. E. \& Seaman, J. (2016). Online report card: Tracking online education in the United States. Babson Survey Research Group.

Al-Rabiaah, A., Temsah, M. H., Al-Eyadhy, A. A., Hasan, G. M., Al-Zamil, F., Al-Subaie, S., ... \& Somily, A. M. (2020). Middle east respiratory syndrome-corona virus (MERS-CoV) associated stress among medical students at a university teaching hospital in Saudi Arabia. Journal of Infection and Public Health, 13(5), 687-691. https://doi.org/10.1016/j.jiph.2020.01.005

Askari, R. (may, 8, 2020). The impact of Covid-19 on higher education in Bangladesh. Dhaka courier. https://dhakacourier.com.bd/news/Column/the-impact-of-covid-19-on-highereducation-in-bangladesh/2397.html

Balkin, R. S., Buckner, D., Swartz, J., \& Rao, S. (2005). Issues in classroom management in an interactive distance education course. International Journal of Instructional Media, 32(4), 363372 .

Baron, R. M. \& Kenny, D. A. (1986). The moderator-mediator variable distinction in social psychological research: Conceptual, strategic and statistical considerations. Journal of Personality and Social Psychology, 51(6), 1173-1182. https://doi.org/10.1037/0022-3514.51.6.1173

Bedford, J., Enria, D., Giesecke, J., Heymann, D. L., Ihekweazu, C., Kobinger, G., ... \& Ungchusak, K. (2020). Covid-19: Towards controlling of a pandemic. The Lancet, 395(10229), 10151018. https://doi.org/10.1016/So140-6736(20)30673-5

Bickel, R. (2012). Multilevel analysis for applied research: It's just regression! Guilford Press.

Bower, M., Dalgarno, B., Kennedy, G. E., Lee, M. J., \& Kenney, J. (2015). Design and implementation factors in blended synchronous learning environments: Outcomes from a cross-case analysis. Computers \& Education, 86, 1-17. https://doi.org/10.1016/j.compedu.2015.03.006

Bozkurt, A. \& Sharma, R. C. (2020). Emergency remote teaching in a time of global crisis due to CoronaVirus pandemic. Asian Journal of Distance Education, 15(1), 1-6.

Brooks, C. \& Grajek, S. L. (april, 9, 2020). Institutional readiness to adopt fully remote learning. EDUCAUSE. https://er.educause.edu/blogs/2020/4/institutional-readiness-to-adoptfully-remote-learning.

Bussmann, S., Johnson, S. R., Oliver, R., Forsythe, K., Grandjean, M., Lebsock, M., \& Luster, T. (2017). On the recognition of quality online course design in promotion and tenure: A survey of higher ed institutions in the western United States. Online Journal of Distance Learning Administration, 20(1), art 1. 
Callaghan, W., Wilson, B., Ringle, C. M., \& Henseler, J. (2007). Exploring causal path directionality for a marketing model using cohen's path method. MATFORSK.

Carrión, G. C., Nitzl, C., \& Roldán, J. L. (2017). Mediation analyses in partial least squares structural equation modeling: Guidelines and empirical examples. In H. Latan and R. D. Noonan (Eds.), Partial least squares path modeling (pp. 173-195). Springer. https://doi.org/10.1007/978-3-319-64069-3_8

Celik, V. \& Yesilyurt, E. (2013). Attitudes to technology, perceived computer self-efficacy and computer anxiety as predictors of computer supported education. Computers $\&$ Education, 6O(1), 148-158. https://doi.org/10.1016/j.compedu.2012.06.008

Chang, I. \& Chen, R. (2020). The impact of perceived usefulness on satisfaction with online parenting resources: The mediating effects of liking and online interaction. Asia-Pacific Education Researcher, 29, 307-317. https://doi.org/10.1007/s40299-019-00484-y.

Child, D. (2006). The essentials of factor analysis. A\&C Black.

Chin, W. W. (1998). The partial least squares approach to structural equation modeling. Modern Methods for Business Research, 295(2), 295-336.

Chin, W. W. (1998a). Commentary: Issues and opinion on structural equation modeling. MIS Quarterly, 22(1), 7-16. 259.

Chin, W. W., Marcolin, B. L., \& Newsted, P. R. (2003). A partial least squares latent variable modeling approach for measuring interaction effects: Results from a Monte Carlo simulation study and an electronic-mail emotion/adoption study. Information Systems Research, 14(2), 189-217. https://doi.org/10.1287/isre.14.2.189.16018.

Cohen, J. (1988). Statistical power analysis for the behavioral sciences. Lawrence Erlbaum Associates, Inc.

Compeau, D. R. \& Higgins, C. A. (1995). Computer self-efficacy: Development of a measure and initial test. MIS Quarterly, 5(1), 189-211. https://doi.org/10.2307/249688

Coopasami, M., Knight, S., \& Pete M. (2017). E-Learning readiness amongst nursing students at the Durban University of Technology. Health Sa Gesondheid, 22(1), 300-306. https://doi.org/10.1016/j.hsag.2017.04.003

Cox, D. R. \& Hinkley, D. V. (1979). Theoretical statistics. CRC Press. https://doi.org/10.1201/b14832

Cutri, R. M. \& Mena, J. (2020). A critical reconceptualization of faculty readiness for online teaching. Distance Education, 41(3), 361-380. https://doi.org/10.1080/01587919.2020.1763167

Cutri, R. M. \& Whiting, E. F. (2018). Opening spaces for teacher educator knowledge in a faculty development program on blended learning course development. Studying Teacher Education, 14(2), 125-140. https://doi.org/10.1080/17425964.2018.1447920

Davis, F. D. (1989). Perceived usefulness, perceived ease of use, and user acceptance of information technology. MIS Quarterly, 3(2), 319-340. https://doi.org/10.2307/249008

Deci, E. L. \& Ryan, R. M. (1985). Intrinsic motivation and self-determination in human behavior. Springer. https://doi.org/10.1007/978-1-4899-2271-7

Denis, B., Watland, P., Pirotte, S., \& Verday, N. (2004). Roles and competencies of the e-tutor. In AAVV (Coord.), Proceedings of the fourth international conference (pp. 150-157). Networked learning.

Eble, K. (1994). Craft of teaching: A guide to mastering the professor's art. Jossey-Bass. 
Falk, R. F. \& Miller, N. B. (1992). A primer for soft modeling. University of Akron Press.

Field, A. (2009). Discovering statistics using SPSS. Sage publications.

Fishbein, M., Jaccard, J., Davidson, A. R., Ajzen, I., \& Loken, B. (1980). Predicting and understanding family planning behaviors. Prentice Hall.

Flores, M. \& Gago, M. (2020). Teacher education in times of Covid-19 pandemic in Portugal: National, institutional and pedagogical responses. Journal of Education for Teaching, 46(4), 1-10. https://doi.org/10.1080/02607476.2020.1799709

Fornell, C. \& Cha, J. (1994). Partial least squares. Advanced Methods of Marketing Research, 407, 5278. https://doi.org/10.1002/0471667 196.ess 1914.pub2

Fornell, C. \& Larcker, D. F. (1981). Structural equation models with unobservable variables and measurement error: Algebra and statistics. Journal of Marketing Research, 18(3), 382-388. https://doi.org/10.1177/002224378101800313

Frydenberg, J. (2007). Persistence in university continuing education online classes. The International Review of Research in Open and Distributed Learning, 8(3), 375-389. https://doi.org/10.19173/irrodl.v8i3.375.

Garrison, D. R. (2011). E-learning in the 21 st century: A framework for research and practice. Taylor \& Francis. https://doi.org/10.4324/9780203838761

Garrison, D. R., Anderson, T., \& Archer, W. (2003). A theory of critical inquiry in online distance education. Handbook of Distance Education, 1, 113-127.

Geisser, S. (1974). A predictive approach to the random effect model. Biometrika, 61(1), 101-107. https://doi.org/10.1093/biomet/61.1.101.

Godoe, P. \& Johansen, T. (2012). Understanding adoption of new technologies: Technology readiness and technology acceptance as an integrated concept. Journal of European Psychology Students, 3(1), art 2. https://doi.org/10.5334/jeps.aq

Gülbahar, Y. \& Adnan, M. (2020). Faculty professional development in creating significant teaching and learning experiences online. In M. Adan (Ed.), Handbook of research on creating meaningful experiences in online courses (pp. 37-58). IGI Global. https://doi.org/10.4018/9781-7998-0115-3.choo4

Hair, J. F., Ringle, C. M., \& Sarstedt, M. (2011). PLS-SEM: Indeed, a silver bullet. The Journal of Marketing Theory and Practice, 19(2), 139-152. https://doi.org/10.2753/MTP10696679190202. https://doi.org/10.15358/9783800653614

Hair, J. F., Hult, G. T. M., Ringle, C., \& Sarstedt, M. (2016). A primer on partial least squares structural equation modeling. Sage.

Hair J. F., Matthews, L. M., Matthews, R. L., \& Sarstedt, M. (2017). PLS-SEM or CB-SEM: Updated guidelines on which method to use. International Journal of Multivariate Data Analysis, 1(2), 107-123. https://doi.org/10.1504/IJMDA.2017.087624

Hair, J. F., Black, W. C., Babin, B. J., Anderson, R. E., \& Tatham, R. L. (1998). Multivariate data analysis. Prentice.

Hardy, J. V. (1998). Teacher attitudes toward and knowledge of computer technology. Computers in the Schools, 14(4), 119-136. https://doi.org/10.1300/Jo25v14no3_11

Hashim, H. \& Tasir, Z. (2014). E-learning readiness: A literature review. International Conference on Teaching and Learning in Computing and Engineering, 7, 267-271.

https://doi.org/10.1109/LaTiCE.2014.58 
Henseler, J. \& Fassott, G. (2010). Testing moderating effects in PLS path models: An illustration of available procedures. In J. Henseler (Ed.), Handbook of partial least squares (pp. 713-735). Springer. https://doi.org/10.1007/978-3-540-32827-8_31

Henseler, J., Ringle, C. M., \& Sarstedt, M. (2015). A new criterion for assessing discriminant validity in variance-based structural equation modeling. Academy of Marketing Science Journal, 43(1), 115-129. https://doi.org/10.1007/s 11747-014-0403-8

Henseler, J., Ringle, C., \& Sinkovics, R. (2009). The use of partial least squares path modeling in international marketing. Advances in International Marketing, 20, 277-320. https://doi.org/10.1108/S1474-7979(2009)0000020014.

Islam, M. Z. (April, 14, 2020). Mobile internet slowest in Bangladesh among 42 countries. The Daily Stars. https://www.thedailystar.net/business/news/mobile-internet-slowestbangladesh-among-42-countries-1892761

Islam, M. K., Islam, Y. M., Hossain, M. E., \& Hoque, M. S. (2016). Articulation of group dynamics of undergraduate students in social media. http://oasis.col.org/handle/11599/2508.

Järvelä, S., Volet, S., \& Järvenoja, H. (2010). Research on motivation in collaborative learning: Moving beyond the cognitive-situative divide and combining individual and social processes. Educational Psychologist, 45(1), 15-27. https://doi.org/10.1080/00461520903433539

Joo, Y. J., Lim, K. Y., \& Kim, N. H. (2016). The effects of secondary teachers' technostress on the intention to use technology in South Korea. Computers \& Education, 95, 114-122. https://doi.org/10.1016/j.compedu.2015.12.004

Kafka, A. C. (2020). Shock, fear, and fatalism: As coronavirus prompts colleges to close, students grapple with uncertainty. The Cronicle of Higher Education.

Khalifeh, G., Noroozi, O., Farrokhnia, M., \& Talaee, E. (2020). Higher education students' perceived readiness for computer-supported collaborative learning. Multimodal Technologies and Interaction, 4(2), 11. https://doi.org/10.3390/mti4020011

Khan, M., Hossain, S., Hasan, M., \& Clement, C. K. (2012). Barriers to the introduction of ICT into education in developing countries: The example of Bangladesh. Online Submission, 5(2), 6180 .

Khan, S. \& Hancioglu, A. (2019). Multiple indicator cluster surveys: Delivering robust data on children and women across the globe. Studies in Family Planning, 50(3), 279-286. https://doi.org/10.1111/sifp.12103

König, J., Jäger-Biela, D. J., \& Glutsch, N. (2020). Adapting to online teaching during Covid-19 school closure: Teacher education and teacher competence effects among early career teachers in Germany. European Journal of Teacher Education, 43(4) 1-15. https://doi.org/10.1080/02619768.2020.1809650

Krejcie, R. V. \& Morgan, D. W. (1970). Determining sample size for research activities. Educational and Psychological Measurement, 30(3), 607-610. https://doi.org/10.1177/001316447003000308

Kyei-Blankson, L., Ntuli, E., \& Blankson, J. (Eds.). (2019). Handbook of research on creating meaningful experiences in online courses. IGI Global. https://doi.org/10.4018/978-1-79980115-3

Li, K., Li, Y., \& Franklin, T. (2016). Preservice teachers' intention to adopt technology in their future classrooms. Journal of Educational Computing Research, 54(7), 946-966. https://doi.org/10.1177/0735633116641694 
Li, Q. \& Ma, X. (2010). A meta-analysis of the effects of computer technology on school students' mathematics learning. Educational Psychology Review, 22(3), 215-243.

https://doi.org/10.1007/s 10648-010-9125-8

Li, W., Lee, A. M., \& Solmon, M. A. (2005). Relationships among dispositional ability conceptions, intrinsic motivation, perceived competence, experience, and performance. Journal of Teaching in Physical Education, 24(1), 51-65. https://doi.org/10.1123/jtpe.24.1.51

Liouville, J. \& Bayad, M. (1998). Human resource management and performances: Proposition and test of a causal model. Human Systems Management, 17(3), 183-192. https://doi.org/10.1177/239700229801200304

Liu, X., Liu, S., Lee, S., \& Magjuka, R. J. (2010). Cultural differences in online learning: International student perceptions. Educational Technology and Society, 13(3), 177-188.

Martin, F., Wang, C., Jokiaho, A., May, B., \& Grübmeyer, S. (2019). Examining faculty readiness to teach online: A comparison of US and German educators. European Journal of Open, Distance and E-Learning, 22(1), 53-69. https://doi.org/10.2478/eurodl-2019-0004.

McIntyre, M. (2020). How coronavirus is affecting the mental health of millions of Americans. https://www.psycom.net/coronavirus-mental-health.html

Mitra, A., Hazen, M. D., LaFrance, B., \& Rogan, R. G. (1999). Faculty use and non-use of electronic mail: Attitudes, expectations and profiles. Journal of Computer-Mediated Communication, 4(3), 297-318. https://doi.org/10.1111/j.1083-6101.1999.tbo0097.x

Mtebe, J. \& Raisamo, R. (2014). Investigating students' behavioural intention to adopt and use mobile learning in higher education in East Africa. International Journal of Education and Development Using ICT, $10(3), 148476$.

Nami, F. \& Vaezi, S. (2018). How ready are our students for technology-enhanced learning? Students at a university of technology respond. Journal of Computing in Higher Education, 30(3), 510-529. https://doi.org/10.1007/s12528-018-9181-5

Noroozi, O. \& Hatami, J. (2019). The effects of online peer feedback and epistemic beliefs on students' argumentation-based learning. Innovations in Education and Teaching International, 56(5), 548-557. https://doi.org/10.1080/14703297.2018.1431143

Notari, M., Baumgartner, A., \& Herzog, W. (2014). Social skills as predictors of communication, performance and quality of collaboration in project-based learning. Journal of Computer Assisted Learning, 30(2), 132-147.

Nunnally, J. C. \& Bernstein, I. H. (1994). Psychometric theory. McGraw-Hill

Osborne, J. W., Costello, A. B., \& Kellow, J. T. (2008). Exploratory factor analysis (EFA) is rightly described as both an art and a science. Best Practices in Quantitative Methods, 86, e6243. https://doi.org/10.4135/9781412995627

Osman, M. E. (2005). Students' reaction to WebCT: Implications for designing online learning environments. International Journal of Instructional Media, 32(4), 353-362.

Parasuraman, A. \& Colby, C. L. (2007). Techno-ready marketing: How and why your customers adopt technology. The Free Press.

Phielix, C., Prins, F. J., \& Kirschner, P. A. (2010). Awareness of group performance in a CSCLenvironment: Effects of peer feedback and reflection. Computers in Human Behavior, 26(2), 151-161. https://doi.org/10.1016/j.chb.2009.10.011

Preacher, K. J. \& Hayes, A. F. (2004). SPSS and SAS procedures for estimating indirect effects in simple mediation models. Behavior Research Methods, Instruments, \& Computers, 36, 717-731. https://doi.org/10.3758/BFo3206553 
Raffo, D. M., Fisher, L. S., \& Raffo, D. M. (2015). Balancing online teaching activities: Strategies for optimizing efficiency and effectiveness. The Free Press.

Rennie, F. \& Morrison, T. (2013). E-learning and social networking handbook: Resources for higher education. Routledge. https://doi.org/10.4324/9780203120279

Renninger, K. A., Cai, M., Lewis, M. C., Adams, M. M., \& Ernst, K. L. (2011). Motivation and learning in an online, unmoderated, mathematics workshop for teachers. Educational Technology Research and Development, 59(2), 229-247. https://doi.org/10.1007/s 11423-0119195-4

Ryan, R. M. \& Deci, E. L. (2000). Intrinsic and extrinsic motivations: Classic definitions and new directions. Contemporary Educational Psychology, 25(1), 54-67. https://doi.org/10.1006/ceps.1999.1020

Ryan, R. M., Connell, J. P., \& Grolnick, W. S. (1992). When achievement is not intrinsically motivated: A theory of internalization and self-regulation in school. Achievement and Motivation: A Social-Developmental Perspective, 167(88), 167-188.

Sahu, P. (2020). Closure of universities due to Coronavirus Disease 2019 (COVID-19): impact on education and mental health of students and academic staff. Cureus, 12(4), e7541. https://doi.org/10.7759/cureus.7541

Sarker, M., Mahmud, R., Islam, M. S., \& Islam, M. K. (2019). Use of e-learning at higher educational institutions in Bangladesh: Opportunities and challenges. Journal of Applied Research in Higher Education, 11(2), 210-223. https://doi.org/10.1108/JARHE-06-20180099.

Shenoy, M. V, Mahendra.M. S. \& Vijay, M. N. (2020). Covid-19. Lockdown: Technology adaption, teaching, learning, student's engagement and faculty experience. Mukt Shabd Journal, 9(4), 698-702.

Slof, B., Nijdam, D., \& Janssen, J. (2016). Do interpersonal skills and interpersonal perceptions predict student learning in CSCL-environments? Computers \& Education, 97, 49-60. https://doi.org/10.1016/j.compedu.2016.02.012

Smith, P. J. (2005). Learning preferences and readiness for online learning. Educational Psychology, 25(1), 3-12. https://doi.org/10.1080/0144341042000294868

Stansfield, M., McLellan, E., \& Connolly, T. M. (2004). Enhancing student performance in online learning and traditional face-to-face class delivery. Journal of Information Technology Education, 3, 173-188. https://doi.org/10.28945/296

Stone, M. (1974). Cross-validatory choice and assessment of statistical predictions. Journal of the Royal Statistical Society, 36(2), 111-147.

Sureshchandar, G. S., Rajendran, C., \& Anantharaman, R. N. (2002). The relationship between service quality and customer satisfaction-a factor specific approach. Journal of Services Marketing, 16(4), 363-379. https://doi.org/10.1108/08876040210433248

Swanson, E. B. (1988). Management information system: Appreciation and involvement. Management Science, 21(2), 178-188. https://doi.org/10.1287/mnsc.21.2.178

Tacq, J. J. \& Tacq, J. (1997). Multivariate analysis techniques in social science research: From problem to analysis. Sage.

Teo, T. (2010). A path analysis of pre-service teachers' attitudes to computer use: Applying and extending the technology acceptance model in an educational context. Interactive Learning Environments, 18(1), 65-79. https://doi.org/10.1080/10494820802231327 
Teo, T., Lee, C. B., \& Chai, C. S. (2008). Understanding pre-service teachers' computer attitudes: Applying and extending the technology acceptance model. Journal of Computer Assisted Learning, 24(2), 128-143. https://doi.org/10.1111/j.1365-2729.2007.00247.x

Toquero, C. M. (2020). Challenges and opportunities for higher education amid the covid-19 pandemic: The Philippine context. Pedagogical Research, 5(4), em0063. https://doi.org/10.29333/pr/7947

Uddin, M. (june, 13, 2020). Effects of the pandemic on the education sector in Bangladesh. The Financial Express. https://thefinancialexpress.com.bd/views/effects-of-the-pandemic-onthe-education-sector-in-bangladesh-1592061447

Ünal, Y., Alır, G., \& Soydal, I. (2014). Students readiness for e-learning: An assessment on hacettepe university department of information management. Communications in Computer and Information Science, 137-147. https://doi.org/10.1007/978-3-662-44412-2_13.

UNESCO. (2020). Covid-19 educational disruption and response. UNESCO.

UNESCO. (2020). Dealing with obstacles to distance learning. UNESCO.

Venkatesh, V. \& Davis, F. D. (2000). A theoretical extension of the technology acceptance model: Four longitudinal field studies. Management Science, 46(2), 186-204. https://doi.org/10.1287/mnsc.46.2.186.11926

Vinzi, V. E., Trinchera, L., \& Amato, S. (2010). PLS path modeling: From foundations to recent developments and open issues for model assessment and improvement. In V. E. Vinzi, W. W. Chin, J. R. Henseler (Eds.), Handbook of partial least squares (pp. 47-82). Springer. https://doi.org/10.1007/978-3-540-32827-8_3

Wang, Y. S., Wu, M. C., \& Wang, H. Y. (2009). Investigating the determinants and age and gender differences in the acceptance of mobile learning. British Journal of Educational Technology, 4O(1), 92-118. https://doi.org/10.1111/j.1467-8535.2007.00809.x

Wilson, J. (2010). Essentials of business research: A guide to doing your research project. Sage.

Xiong, Y., So, H. J., \& Toh, Y. (2015). Assessing learners' perceived readiness for computersupported collaborative learning (CSCL): A study on initial development and validation. Journal of Computing in Higher Education, 27(3), 215-239. https://doi.org/10.1007/s 12528015-9102-9

Zimmerman, B. J. (2000). Self-efficacy: An essential motive to learn. Contemporary Educational Psychology, 25(1), 82-91. https://doi.org/10.1006/ceps.1999.1016

\section{Brief CV of the author}

\section{Mohammad Rokibul Kabir}

He is a Post-Doctoral Research Fellow at University Malaysia Perlis (UNiMAP) since 1st June 2020. He has been awarded PhD in 2017 by the University of Chittagong, Bangladesh. Before that, he completed his M.Phil, MBA and BBA from the same university. He has also passed LLB from the University of Information Technology and Sciences. He is serving East Delta University as the Associate Professor in the School of Business Administration. He has around forty publications in different journals and he is highly interested in Accounting, Finance and Business Technology related research. Dr. Kabir is currently leading the School of Business Administration of East Delta University, Bangladesh as the Associate Dean. He is a member of Chittagong Bar Association, 
Bangladesh. ORCID ID: https://orcid.org/0000-0003-1186-8043. Email: rokibul.k@eastdelta.edu.bd 